Gut, 1986, 27, S1, 96-102

\title{
Effect of branched chain amino acid infusions on body protein metabolism in cirrhosis of liver
}

\author{
P D WRIGHT, J D HOLDSWORTH, P DIONIGI, M B CLAGUE, AND O F W JAMES \\ From the Departments of Surgery and Medicine, University of Newcastle on Tyne, Newcastle on Tyne
}

SUMmARY Thirty seven patients with established cirrhosis of the liver were subjected to measurement of body protein metabolism using $\mathrm{L}-\left(1-{ }^{14} \mathrm{C}\right)$ labelled leucine as a tracer. The effects of disease severity and those of solutions containing $0 \%, 16 \%, 35 \%, 53 \%$, and $100 \%$ branched chain amino acids were evaluated. Significant increases in protein synthesis were noted with solutions containing $35 \%, 53 \%$, and $100 \%$ branched chain amino acids, but in patients receiving $100 \%$ branched chain amino acids without additional essential amino acid supplement the increase in synthesis was matched by a significant increase in protein breakdown. Protein balance was thus improved only in patients receiving $35 \%$ and $53 \%$ branched chain amino acids. It was concluded that the high increase in protein breakdown in patients receiving $100 \%$ branched chain amino acids was undesirable, and such a solution should not be recommended for clinical use.

The most characteristic of the changes in plasma amino acids that occur in cirrhosis of the liver are a lowering of the three branched chain amino acids (BCAA) leucine, isoleucine, and valine and an increase in methionine and the aromatic amino acids phenylalanine and tyrosine. ${ }^{1-6}$ Infusion of amino acid solutions enriched with $\mathrm{BCAA}^{7-12}$ and BCAA alone ${ }^{81314}$ have been used to modify this amino acid profile with some apparent beneficial effects on portal systemic encephalopathy; little evidence, however, has been documented concerning the effects of these infusions on other metabolic variables, notably protein metabolism.

Body protein metabolism can be measured using various techniques in which the kinetics of a labelled amino acid are analysed. ${ }^{15}$ A recent report, ${ }^{16}$ using $\mathrm{U}\left({ }^{14} \mathrm{C}\right)$ tyrosine, suggested that the administration of BCAAs diminished protein breakdown and synthesis in cirrhosis of the liver. The use of tyrosine, a non-essential amino acid that has a small body pool and is metabolised by the liver, makes interpretation of these results difficult. Leucine is a more appropriate choice for studying patients with cirrhosis of the liver as this amino acid has a larger pool size, is an essential amino acid, and is metabolised by skeletal muscle. Recent refinements in technique using a double isotope infusion of sodium $\left({ }^{14} \mathrm{C}\right)$ bicarbonate followed by $\mathrm{L}-\left(1-{ }^{14} \mathrm{C}\right)$

Correspondence to: Mr P D Wright. Freeman Hospital, Freeman Road, High Heaton. Newcastle upon Tyne NE7 7DN, England. leucine ${ }^{17}$ have shown that a single metabolic study can be completed in four hours with all measurements carried out on plasma samples, obviating the need to collect urine or expired air. ${ }^{18}$ The aims of this study were twofold: firstly, to evaluate body protein metabolism and plasma amino acids in patients with cirrhosis of the liver with reference to disease severity; and secondly, to assess the effects of intravenous infusions of different amino acid solutions of varying BCAA content on protein metabolism. As the metabolism of BCAAs may be influenced by insulin ${ }^{19}{ }^{20}$ plasma insulin was also measured during these studies.

\section{Patients and methods}

Thirty seven patients with histologically confirmed stable cirrhosis were studied. The severity of the disease was assessed on the basis of abnormalities in the serum bilirubin and albumin prothrombin time, the quantity of ascites and the level of encephalopathy in accordance with the Pugh modification of Child's classfication. ${ }^{21}$ Patients were excluded if there was evidence of current infection or variceal bleeding, or if there had been a recent noticeable change in ascites. Patients were also excluded if they had had surgery or blood transfusion within the preceding four weeks, if they had diabetes mellitus, or had received steroids.

Five different intravenous fluid regimens were 
Table 1 Details of patients within nutritional groups and of those additional patients who failed to complete full study protocol but who provided sufficient data to be used for assessing disease severity

\begin{tabular}{|c|c|c|c|c|c|c|}
\hline \multicolumn{2}{|l|}{ Group $(n=)$} & $\begin{array}{l}\text { Sex } \\
M: F\end{array}$ & $\begin{array}{l}\text { Age } \\
(\operatorname{mean}(S D))\end{array}$ & \multicolumn{3}{|c|}{$\begin{array}{l}\text { Child's grading } \\
\text { system }\end{array}$} \\
\hline $100 \%$ BCAA & (7) & 52 & $58(7)$ & 1 & 2 & 4 \\
\hline $53 \%$ BCAA & (6) & $\begin{array}{ll}3 & 3\end{array}$ & $60(5)$ & 1 & 4 & 1 \\
\hline $35 \%$ BCAA & (6) & 15 & 63 (12) & 3 & 2 & 1 \\
\hline $16 \%$ BCAA & (6) & 33 & $59(10)$ & 3 & 3 & 0 \\
\hline Dextrose & (7) & 34 & $58(12)$ & 2 & 2 & 3 \\
\hline Additional & 5 & 41 & $58(8)$ & 2 & 1 & 2 \\
\hline Totals & 37 & 1918 & $59(9)$ & 12 & 14 & 11 \\
\hline
\end{tabular}

used and patients were randomly allocated into groups on this basis (32 patients). Table 1 gives details of the patients and groups. Those patients who failed to complete the full study schedule, but who provided additional data for the assessment of disease severity, were also included $(n=5)$. The nutritional groups were of comparable ages, but there was some variability in the sex allocation and child's grades within each group.

\section{STUDY SCHEDULE}

Each of the 32 patients in the five study groups underwent two protein metabolic studies (two patients failed to complete the second study due to difficulties with blood sampling, but provided sufficient blood to complete the plasma amino acid data). The first study was used to assess disease severity (Child's classification) in all subjects and each first study was also used as a control against which metabolic changes brought about by the intravenous fluid regimens could be assessed. An oral liquid feed was given during the first study, whereas during the second study patients received the intravenous solution to which they had been allocated. After an overnight fast the oral feed was started, given as aliquots each half hour and continued throughout the first metabolic study, which began one and a half hours after the start of the oral feeding. When the first study had been completed nutrition was changed to the appropriate intravenous formulation and continued for a further 24 hours, the second protein metabolic study being carried out during the final four hours.

\section{NUTRITION}

Clinifeed 400 was selected for the control studies as this is a liquid oral feed and thus easy to administer. It was given at the rate of $0.8 \mathrm{ml} / \mathrm{kg}^{-1} / \mathrm{hour}^{-1}$, equivalent to $3.84 \mathrm{mg}$ nitrogen and $0.64 \mathrm{cal} / \mathrm{kg}^{-1 /}$ hour $^{-1}$.

Four amino acid solutions of varying BCAA content were used: a) $100 \%$ BCAA (4\% BCAA, Travenol Laboratories Ltd); b) 53\% BCAA (Synthamin $17+4 \%$ BCAA); c) $35 \%$ BCAA (Hepatamine); and d) $16 \%$ BCAA (Synthamin 14). All of these amino acid solutions were given with $10 \%$ dextrose, and therefore $10 \%$ dextrose alone was also evaluated. Patients with liver disease may be intolerant of intravenous amino acids ${ }^{4}$, and to avoid this the infusion rate of the amino acid solutions was adjusted so that the nitrogen input was $2 \cdot 11 \mathrm{mg} / \mathrm{kg}^{-1} /$ hour $^{-1}$. The carbohydrate content of each solution was adjusted so that the calorific input was 0.64 $\mathrm{cal} / \mathrm{kg}^{-1} / \mathrm{hour}^{-1}$.

Details of the calorific content and volumetric infusion rates of the five intravenous infusions.

MEASUREMENTS OF BODY PROTEIN METABOLISM Primed constant rate infusions of sodium $\left(1-{ }^{14} \mathrm{C}\right)$ bicarbonate and $\mathrm{L}-\left(1-{ }^{14} \mathrm{C}\right)$ leucine were given, as described by Clague et al. ${ }^{17}$ The sodium $\left({ }^{14} \mathrm{C}\right)$ bicarbonate was used to calibrate the body bicarbonate pool so that the entry rate of ${ }^{14} \mathrm{CO}_{2}$ into the pool from the oxidation of $\mathrm{L}-\left(1-{ }^{14} \mathrm{C}\right)$ leucine could be determined during the second isotope infusion. After taking the blood for background radioactivity

Table 2 Volumetric composition (\%), infusion rates $\left(\mathrm{ml} / \mathrm{kg}^{-1} / \mathrm{hour}^{-1}\right)$, and calorific infusion rates (cal/kg-1/ hour ${ }^{-1}$ ) of components of each solution*

\begin{tabular}{|c|c|c|c|c|}
\hline Solution & $\begin{array}{l}B C C A \\
(\%)\end{array}$ & $\begin{array}{l}\text { Volume } \\
\%\end{array}$ & $\begin{array}{l}\text { Volumetric } \\
\text { infusion } \\
\text { rate }\end{array}$ & $\begin{array}{l}\text { Calorific } \\
\text { infusion } \\
\text { rate }\end{array}$ \\
\hline $\begin{array}{l}4 \% \text { BCAA } \\
+ \\
10 \% \text { dextrose }\end{array}$ & 100 & $\begin{array}{l}24.97 \\
75 \cdot 03\end{array}$ & 1.906 & $\begin{array}{l}0.068^{\dagger} \\
+ \\
0.572\end{array}$ \\
\hline $\begin{array}{c}\text { Synthamin } 17 \\
+ \\
4 \% \text { BCAA } \\
+ \\
10 \% \text { dextrose }\end{array}$ & 53 & $\begin{array}{r}9 \cdot 57 \\
85 \cdot 65\end{array}$ & $1 \cdot 714$ & $\begin{array}{c}0.053 \dagger \\
+\end{array}$ \\
\hline $\begin{array}{l}\text { Hepatamine } \\
\quad+ \\
10 \% \text { dextrose }\end{array}$ & 35 & $\begin{array}{l}10 \cdot 56 \\
89 \cdot 44\end{array}$ & $1 \cdot 647$ & $\begin{array}{l}0.051 \dagger \\
+ \\
0.589\end{array}$ \\
\hline $\begin{array}{l}\text { Synthamin } 14 \\
+ \\
10 \% \text { dextrose }\end{array}$ & 16 & $\begin{array}{r}9.05 \\
90 \cdot 95\end{array}$ & $1 \cdot 636$ & $\begin{array}{c}0.045 \dagger \\
+ \\
0.595\end{array}$ \\
\hline $10 \%$ dextrose & & $100 \cdot 00$ & $1 \cdot 600$ & $0 \cdot 64$ \\
\hline
\end{tabular}

†Allowances made for calories that may be derived from amino acids $\left(3.57\right.$ calg $\left.^{-1}\right)$

*Final rate of nitrogen was $2.11 \mathrm{mg}$ and that of calories 0.64 $\mathrm{kg}^{-1 / \text { hour }^{-1} \text {. }}$ 
the sodium $\left({ }^{1+} \mathrm{C}\right)$ bicarbonate was infused for one and a half hours, with blood sampling during the final half hour to determine the plateau of ${ }^{14} \mathrm{CO}_{2}$ in plasma. The isotope infusion was then changed to the $\mathrm{L} 1-\left(1-{ }^{14} \mathrm{C}\right)$ leucine, which continued for a further two and a half hours, blood being taken three times during the last hour to determine plateau activity of ${ }^{19} \mathrm{CO}_{2}$ and ${ }^{14} \mathrm{C}$-leucine in plasma. Separation of ${ }^{1+} \mathrm{C}$-activity from blood was carried out on the day of collection and counted in a Packard Tricarb liquid scintillation counter.

Permission was granted by the isotope advisory panel and local ethical committee for two studies $(50 \mu \mathrm{Ci}$ total radiation) in subjects 45 years or older who had given informed consent.

\section{CALCULATION OF BODY PROTEIN METABOLISM}

The body is composed of a number of intracellular and extracellular pools of amino acids. The number and size of these pools is not considered to be important when administering a primed constant rate infusion of a labelled amino acid to measure protein metabolism, provided sufficient time elapses to permit the isotope to equilibrate within each pool. Based on this assumption, the following mathematical relation can be applied to relate the various components of leucine metabolism:

$$
\mathrm{q}=\mathrm{b}+\mathrm{i}=\mathrm{s}+\mathrm{c} \quad\left(\mathrm{gm} / \mathrm{kg}^{-1} / \mathrm{d}^{-1}\right)
$$

where,

$$
\begin{aligned}
& q=\text { leucine turnover, } \\
& b=\text { leucine entering the amino acid pool from } \\
& \text { protein breakdown, } \\
& i=\text { intake (oral or intravenous) of leucine, } \\
& s=\text { leucine incorporated into newly synthe- } \\
& \text { sised protein, } \\
& c=\text { leucine catabolism or oxidation. }
\end{aligned}
$$

Having calculated the rates of leucine released from (b) and incorporated into (s) protein, these values were converted into those for whole body protein, of which leucine represents $8 \%$. Protein balance was calculated by subtracting breakdown from synthesis (s-b).

\section{DETERMINATION OF PLASMA INSULIN}

This was measured on each of the blood samples B and $\mathrm{C}$, using a single antibody radioimmunoassay. ${ }^{22}$

\section{STATISTICAL ANALYSIS}

Results were presented as the mean $+1 \mathrm{SD}$. Paired $t$ tests were used within nutritional groups and for comparison between group analysis of variance (Anovar) and linear regression analysis. The Child's data were subjected to analysis of variance for regression on grouped data (Regova). ${ }^{2.3}$

\section{Results}

EFFECT OF DISEASE SEVERITY

Comparison was made between results obtained in patients with Child's grade A disease $v$ patients with grades $\mathrm{B}$ and $\mathrm{C}$ disease.

\section{Leucine and protein metabolism (Table 3)}

There were no significant differences in leucine turnover or catabolism, nor in body protein synthesis, breakdown, or balance between the three Child's groups.

\section{Plasma insulin (Table 3)}

No significant differences were detected in the concentration of insulin between the three grades of disease, although the concentration of insulin was noted to be higher in the patients with the least severe disease (grade A) than in the patients with more severe disease (grades B and C).

\begin{tabular}{|c|c|c|c|c|}
\hline Metabolic & Child's grading system & & & Regova \\
\hline measurement & $A(n=12)$ & $B(n=14)$ & $C(n=I I)$ & \\
\hline Leucine turnover & $(0.25(0 \cdot 08)$ & $0.27(0.08)$ & $0.27(0.06)$ & NS \\
\hline Leucine catabolism & $0.04(0 \cdot(02)$ & $0.04(0 \cdot 01)$ & $0.06(0 \cdot 02)$ & NS \\
\hline Protein synthesis & $2.52(0.81)$ & $2.83(0.89)$ & $2.63(0.56)$ & NS \\
\hline Protein breakdown & $2.28(0.97)$ & $2.62(1.01)$ & $2.58(0.70)$ & NS \\
\hline Protein balance & $0 \cdot 24(0 \cdot 30)$ & $0.21(0 \cdot 15)$ & $0.05(0 \cdot 25)$ & NS \\
\hline Insulin & $20 \cdot 2(9 \cdot 9)$ & $14 \cdot 6(12 \cdot())$ & $11 \cdot 6(9 \cdot 1)$ & NS \\
\hline
\end{tabular}

\section{EFFECTOF THE INTRAVENOUS INFUSIONS}

Leucine and protein metabolism (Table 4)

When the comparison was made within each study group between the control study and the infusion study (study $1 \quad v 2$ ) infusion of dextrose alone

Table 3 Results for body leucine and protein metabolism (mean (SD)g/kg ${ }^{-1} / \mathrm{days}^{-1}$ ) and plasma insulin (mean (SD) $\mu U / m l^{-1}$ ) 
Table 4 Leucine and protein metabolism (mean(SD)g/ $\mathrm{kg}^{-1} /$ day ') and plasma insulin (mean (SD) $\mu U / \mathrm{ml}$ ') for five nutritional groups during first and second metabolic studies

\begin{tabular}{|c|c|c|c|c|c|c|c|}
\hline Metabolic variable & Study & $\begin{array}{l}B C A A \quad 100 \% \\
(n=6)\end{array}$ & $\begin{array}{l}B C A A \quad 53 \% \\
(n=6)\end{array}$ & $\begin{array}{l}B C A A \quad 35 \% \\
(n=6)\end{array}$ & $\begin{array}{l}B C A A \quad 16 \% \\
(n=6)\end{array}$ & $\begin{array}{l}\text { Dextrose } \\
(n=6)\end{array}$ & Anovar \\
\hline \multirow[t]{3}{*}{ Leucine turnover } & 1 & $0 \cdot 24(0 \cdot 06)$ & $0.31(0.07)$ & $0.23(0 \cdot 06)$ & $0.27(0.10)$ & $(0.29(0.07)$ & NS \\
\hline & 2 & $0.47(0.06)^{* * *}$ & $(0.32(0.09)$ & $0 \cdot 26(0 \cdot(02)$ & $0 \cdot 26(0.09)$ & $0.24(0 \cdot() 6)^{*}$ & \\
\hline & $2-1$ & $0 \cdot 23(0 \cdot 04)$ & $0 \cdot 01 \quad(0 \cdot 06)$ & $(0 \cdot 03 \quad(0 \cdot() 6)$ & $-(0 \cdot 0) 1(0 \cdot() \cdot 3)$ & $-0.05(0.03)$ & $\mathrm{p}<() \cdot()()_{1} \mathrm{l}$ \\
\hline \multirow[t]{3}{*}{ Leucine catabolism } & 1 & $0 \cdot 05(0.02)$ & $0 \cdot 05(0 \cdot 01)$ & $0 \cdot(04(0 \cdot() 1)$ & $0 \cdot(04 \quad(0 \cdot() 2)$ & $0 \cdot 06((0 \cdot 03)$ & NS \\
\hline & 2 & $0 \cdot 14(0 \cdot 04)^{* *}$ & $(0.05(0.02)$ & $0 \cdot(04(0 \cdot 01)$ & $0 \cdot\left(03(0 \cdot() 2)^{* * *}\right.$ & $0 \cdot(04(0 \cdot(02)$ & \\
\hline & $2-1$ & $0 \cdot 09(0 \cdot 04)$ & $0 \cdot 00 \quad(0 \cdot 02)$ & $0 \cdot(00(0)(01)$ & $-0 \cdot() 1 \quad(0 \cdot() 1)$ & $-0 \cdot() 2(() \cdot() 2)$ & $\mathrm{p}<() \cdot()(0) 1$ \\
\hline \multirow[t]{3}{*}{ Protein synthesis } & 1 & $2 \cdot 47(0 \cdot 64)$ & $3.25(0.77)$ & $2 \cdot 34(0 \cdot 68)$ & $2 \cdot 82(1 \cdot 04)$ & $2.76(0.59)$ & NS \\
\hline & 2 & $4 \cdot 06(0 \cdot 61)^{* * *}$ & $3 \cdot 28(0 \cdot 85)$ & $2 \cdot 71(0 \cdot 19)$ & $2.93(() \cdot 91)$ & $2.49(0.63)$ & \\
\hline & $2-1$ & $1.59(0 \cdot 24)$ & $0 \cdot(03 \quad(0.63)$ & $0.37(0.77)$ & $(0.11(0.35)$ & $-0 \cdot 27(0 \cdot 36)$ & $\mathrm{p}<() \cdot()(0)$ \\
\hline \multirow[t]{3}{*}{ Protein breakdown } & 1 & $2 \cdot 28(0 \cdot 78)$ & $3 \cdot 03(0.91)$ & $2 \cdot 11(0.71)$ & $2.53(1.19)$ & $2 \cdot 81(0 \cdot 9(0)$ & NS \\
\hline & 2 & $3 \cdot 85(0.74)^{* * * *}$ & $3 \cdot 10(1 \cdot 07)$ & $2 \cdot 67(0 \cdot 27)$ & $3.06(1.11)^{* * *}$ & $2.95(0 \cdot 8(0)$ & \\
\hline & $2-1$ & $1 \cdot 57(0 \cdot 47)$ & $0.07(0.77)$ & $0.56(0.78)$ & $0 \cdot 53(0 \cdot 32)$ & $0 \cdot 14(0 \cdot 35)$ & $\mathrm{p}<0(0 \cdot()(0) 1$ \\
\hline \multirow[t]{2}{*}{ Protein balance } & 1 & $0 \cdot 19(0 \cdot 20)$ & $0.21 \quad(0.23)$ & $(0 \cdot 23 \quad(0 \cdot(04)$ & $(0 \cdot 28(0 \cdot 16)$ & $-0.05(0.41)$ & NS \\
\hline & $2-1$ & $0.02(0.47)$ & $-0 \cdot(03(0 \cdot 20)$ & $-0 \cdot 19(0 \cdot 15)$ & $-0 \cdot 41(() \cdot 12)$ & $-0 \cdot 41(0 \cdot 25)$ & $\mathrm{p}<0.0 .5$ \\
\hline \multirow[t]{3}{*}{ Insulin } & 1 & $(18 \cdot 6)$ & $18 \cdot 9 \quad(6 \cdot 0)$ & $(27 \cdot 2)$ & $(9 \cdot(0)$ & $(20 \cdot())$ & NS \\
\hline & 2 & $33 \cdot 2 \quad(17 \cdot 6)$ & $43 \cdot 1 \quad(25 \cdot 6)$ & $(22 \cdot())$ & $(15 \cdot())$ & $(25 \cdot 4)$ & \\
\hline & $2-1$ & $8 \cdot 0 \quad(7 \cdot 4)$ & $24 \cdot 2 \quad(25 \cdot 6)$ & $(13 \cdot 8)$ & $16.5 \quad(16.9)$ & $(13.9)$ & NS \\
\hline
\end{tabular}

Significantly different $1 \vee 2 \mathrm{p}={ }^{*}<0 \cdot 05 ;{ }^{* *}<0 \cdot 01 ;{ }^{* * *}<0 \cdot(001$.

resulted in a significant fall in both leucine turnover and catabolism, although no significant changes were seen in body protein synthesis and breakdown. The net effect of these small changes in synthesis and breakdown led to negative protein balance $(p<0 \cdot 01)$. By contrast, infusion of the $100 \%$ BCAA solution led to high increases in leucine turnover and catabolism and body protein synthesis and breakdown, but as the changes in synthesis and breakdown were of a similar order there was no net change in protein balance. When the effects of infusion of amino acid solutions with increasing amounts of BCAA $(16 \%, 35 \%$ and $53 \%)$ were examined, it was seen that the metabolic variables did not change to the same extent as with dextrose alone or $100 \%$ BCAA. The $16 \%$ BCAA solution led to a significant increase in body protein breakdown and consequent negative protein balance $(p<0 \cdot 001) ; 35 \%$ BCAA induced a significant fall in protein balance $(\mathrm{p}<0.05)$; and $53 \%$ BCAA did not lead to significant changes in any of the calculated components.

Comparison between the groups showed no significant differences between the control studies (study 1), but highly significant differences were detected in all the metabolic variables on the basis of changes from the first to the second studies (study 2-1). The significance of these differences for leucine turnover and catabolism and body protein synthesis and breakdown were attributed to the high increases that occurred in those patients given the $100 \%$
BCAA. The significance of the differences in the changes in protein balance was due to the negative balance observed with infusion of the $16 \%$ BCAA and dextrose alone.

Linear regression analysis of the leucine and protein metabolic measurements against BCAA content of the infused solution showed a close correlation with leucine catabolism $(\mathrm{r}=0.90)$ and turnover $(r=0 \cdot 88)$, a detectable correlation with protein synthesis $(r=0.76)$, but only a poor correlation with protein breakdown and balance $(r=0.59$ and $0 \cdot 52$, respectively).

\section{Plasma Insulin (Table 4)}

A wide range in the mean concentrations of insulin was observed between the five groups. The concentrations of insulin were increased by the intravenous infusions in all groups (study 2). No significance, however, was attached to these findings, probably because of the wide variation in insulin concentration within the groups.

\section{Discussion}

This study suggests that on the basis of Child's classification body protein metabolism does not change with increasing severity of cirrhosis. This is probably because skeletal muscle forms the bulk of body protein and as the method used to measure protein metabolism cannot distinguish between metabolism in different tissues changes in protein 
synthesis and breakdown due to liver function will be masked, liver protein being only a relatively small component of whole body protein. As no differences were detected in protein metabolism between the three grades of disease severity it is unlikely that the uneven distribution of patients with different grades of disease between the five nutritional groups will have adversely influenced the results obtained from these groups. This contention is further supported by the absence of differences in the control studies between the nutritional groups.

It has been suggested that infusion of large quantities of leucine at the same time as measuring protein metabolism with $\mathrm{L}-\left(1-{ }^{14} \mathrm{C}\right)$ leucine may invalidate the technique. ${ }^{24}$ As the quantity of leucine used in protein breakdown and synthesis must remain fixed in relation to the total amino acids utilised, however, the method is valid in these circumstances. The same cannot be said for leucine turnover and catabolism, and therefore these two components were not converted into whole body protein equivalents. Infusion of large amounts of leucine will increase turnover by enlarging the leucine content of the body amino acid pool and will increase catabolism, because any leucine present in excess of the amount required for protein synthesis will be oxidised, the body being unable to store excess amino acids. This was supported by our results in that both leucine turnover and catabolism correlated with the increasing amounts of leucine in the infused solutions. As the correlation of protein synthesis and breakdown with the BCAA content of the infusions was much poorer, the high increases observed in those patients receiving only BCAA $(100 \%$ BCAA) may thus be a feature particular to giving only these three amino acids and not simply due to increasing the BCAA content of the infusion.

Patients with cirrhosis differ metabolically from subjects in whom $\mathrm{L}-\left(1-{ }^{14} \mathrm{C}\right)$ leucine has previously been used to measure body protein metabolism, ${ }^{172526}$ particularly because of the presence or absence of ascites. The difference in the quantity of ascites between the patients with cirrhosis might be regarded as a source of error in the measurement of protein metabolism in this disease, as the ascites represents a variable extracellular amino acid pool. With a constant rate of infusion, however, this possible variation in pool size is not regarded as important, provided sufficient time is allowed for equilibration of the labelled amino acid within all amino acid pools.

Another aspect of metabolism that has to be considered when measuring protein metabolism with $\mathrm{L}-\left(1-{ }^{14} \mathrm{C}\right)$ leucine is the effect of insulin on leucine metabolism. Leucine is a potent stimulant to the secretion of insulin, ${ }^{19}$ and in turn, insulin lowers the plasma concentration of BCAA, including leucine. ${ }^{20}$ This relation could represent another potential source of error in the measurement of protein metabolism as the turnover and catabolism of leucine may be influenced by fluctuations in the concentration of plasma insulin, especially when cirrhosis is associated with increased peripheral insulin concentration. ${ }^{27}$ Furthermore, the results could have been influenced in a similar manner during the intravenous infusions as a consequence of the differing BCAA content of the solutions. The results of plasma insulin concentration do not seem to support these arguments. Insulin concentrations were observed in the patients with grades B and C severity and although all five infusions induced a rise in insulin, this was similar for each infusion.

The findings of this study do not agree with those of O'Keefe et al. ${ }^{16}$ In their study, however, a different labelled amino acid, $\mathrm{U}\left({ }^{14} \mathrm{C}\right)$ tyrosine, was used to determine protein metabolism. Furthermore, the rates of the metabolic components were given in $\mathrm{g} / \mathrm{d}^{-1}$, no allowance being made for variations in patient weight, and BCAA were given orally, thus making comparison with the current study difficult.

Infusion of both dextrose alone and the $16 \%$ BCAA solution resulted in negative protein balance, although the underlying mechanism with each infusion, due to changes in protein synthesis and breakdown, was different. The small fall in synthesis and increase in breakdown with dextrose alone can be interpreted as body protein metabolism responding to an absence of dietary amino acids. With infusion of $16 \% \mathrm{BCAA}$ the negative protein balance was due to breakdown, increasing to a greater extent than synthesis. As the infusions were given for 24 hours and the amounts infused were less than is normally recommended for total intravenous nutrition, ${ }^{28}$ the quantity of amino acids in the $16 \%$ BCAA formulation may have been sufficient to preserve protein synthesis, but, nevertheless, the suboptimal amount of amino acids would have been insufficient to prevent a rise in breakdown after 24 hours. It has previously been reported that protein metabolism changes in response to nutrition by an increase in protein synthesis, without a corresponding increase in breakdown. ${ }^{29}$ These responses, however, were documented over a few hours and not 24 hours as in this study.

Better protein balance was observed in the two groups receiving the branched chain enriched amino acid solutions ( $35 \%$ and $53 \% \mathrm{BCAA})$ and the group receiving BCAA alone (100\% BCAA). This phenomenon is again related to different patterns of protein synthesis and breakdown within the groups; possibly the most interesting feature being the high 
increase in both measurements observed with the $100 \%$ BCAA infusion. The increase in protein synthesis with this infusion was not entirely unexpected: experimental work has shown that leucine can increase protein synthesis, ${ }^{30}{ }^{31}$ that BCAA infusions can increase total liver nitrogen ${ }^{32}$; and that branched chain keto acids stimulate albumin synthesis. ${ }^{33}$ The rise in protein breakdown associated with this infusion was of particular interest as this has not been reported previously. These findings may be explained if the above mentioned in vitro effects of leucine on skeletal muscle ${ }^{3031}$ also occur in vivo. By infusing large quantities of leucine we may have invoked this response. To have fuelled the high level of muscle protein synthesis with amino acids, when muscle protein breakdown was diminished and only three of the essential amino acids were infused, the observed total net increase in protein breakdown would only have been due to a secondary increase in other tissues. If we analyse our results on this basis the possible benefits, in terms of protein synthesis and balance conferred by infusion of BCAA alone (100\% BCAA), may thus be counteracted by the increase in protein breakdown.

Although the intravenous solutions administered during this study were given to subjects with stable cirrhosis, in clinical practice it is not these patients who would receive such infusions. The clinical role of tailored branched chain amino acid preparations would be in the management of acutely ill cirrhotic patients, such as those with bleeding from oesophageal varices or postoperative patients. As such patients are limited in number and because they are metabolically unstable, it was considered necessary to evaluate the infusions in patients with stable cirrhosis. The findings suggest that if amino acid solutions were used in the management of unstable cirrhosis then to obtain optimal protein metabolic function the composition should conform to that of either the $53 \%$ or the $35 \%$ BCAA formulations, these being the two solutions which led to satisfactory protein balance without affecting underlying protein synthesis and breakdown to the extent observed with $100 \%$ BCAA. Furthermore, both these solutions contained all the essential amino acids, and they were considered to have the most desirable effect on plasma amino acid concentrations. More work is now required to assess the effects of these infusions in patients with unstable cirrhosis.

\section{References}

1 Iber FL, Rosen H, Levenson SM, Chalmers TC. The plasma amino acids in patients with liver failure. $J L a b$ Clin 1975; 50: 417-25.
2 Richmond J, Girdwood RH. Observations on amino acid absorption. Clin Sci 1962; 22: 301-14.

3 Iob L, Coon WW, Sloan M. Free amino acids in liver, plasma and muscle of patients with cirrhosis of the liver. J Surg Res 1967; 7: 41-3.

4 Fischer JE, Yoshimura N, Aguirre A, et al. Plasma amino acids in patients with hepatic encephalopathy. Am J Surg 1974; 127: 40-7.

5 Rosen HM, Yoshimura N, Hodgman JM, Fischer JE. Plasma amino acid patterns in hepatic encephalopathy of differing aetiology. Gastroenterology 1977; 72: 483-7.

6 Morgan MY, Milsom JP, Sherlock S. Plasma ratio of valine leucine and isoleucine to phenylalanine and tyrosine in liver disease. Gut 1978; 19: 1068-73.

7 Fischer JE, Rosen HM, Ebeid AM, James JH, Keane JM, Soeters PB. The effect of normalisation of plasma amino acids on hepatic encephalopathy in man. Surgery 1976; 80: 77-91.

8 Amano K. Clinical studies in the treatment of hepatic encephalopathy by amino acid infusion. Acta Schol Med Univ Gifu 1979; 27: 131-55.

9 Fiaccordi F, Chinelli F, Pelosi G, et al. Selective amino acid solutions in hepatic encephalopathy treatment. La Ricerca Clinica E Laboratorio 1980; 10: 411-22.

10 Marchesisn G, Soli M, Dondi C, et al. Prevalence of subclinical hepatic encephalopathy in cirrhotics and relationship to plasma amino acid imbalance. Dig Dis Sci 1980; 25: 763-8.

11 Egberts EH, Hamster W, Jurgens P, et al. Effect of branched chain amino acids on latent portal-systemic encephalopathy. In: Walser M, Williamson JR, eds. Metabolism and clinical implications of branched chain amino and keto acids. Elsevier: North Holland, 1981; 453-63.

12 Okada A, Kamata S, Kim CW, Kawashima Y. Treatment of hepatic encephalopathy with BCAA-rich amino acid mixture. In: Walser M, Williamson JR, eds. Metabolism and clinical implications of branched chain amino and keto acids. Elsevier: North Holland, 1981; 447-52.

13 Capocaccia L, Calcaterra V, Cangiano C, et al. Therapeutic effect of branched chain amino acids in hepatic encephalopathy: a preliminary study. In: Orloff MJ, Stipa S, Ziparo V, eds. Serona Symposium No 34. Medical and surgical problems in portal hypertension. London: Academic Press, 1980: 239-49.

14 Wahren J, Eriksson S, Hagenfeldt L. The influence of branched chain amino acids and keto acids on arterial concentrations and brain exchange of amino acids in man. In: Walser M, Williamson JR, eds. Metabolism and clinical implications of branched chain amino and keto acids. Elsevier: North Holland, 1981: 471-88.

15 Waterlow JC, Garlick PJ, Millward DJ. Summary of methods of measuring total protein turnover. In: Protein turnover in mammalian tissues and in the whole body. Elsevier: North Holland, 1978: 327-38.

16 O'Keefe SJD, Abraham RR, Davis M, Williams R. Protein turnover in acute and chronic liver disease. Acta Chir Scand 1981; 507: (suppl) 91-101.

17 Clague MB, Keir MJ, Wright PD, Johnston IDA. The 
effects of nutrition and trauma on whole-body protein metabolism in man. Clin Sci 1983; 65: 165-75.

18 Clague MB, Keir MJ, Wright PD. Development of a technique for measuring the oxidation rate of ${ }^{14} \mathrm{C}$ labelled substances from ${ }^{14} \mathrm{CO}_{2}$ production without the need for collection of expired air. Clin Sci 1981; 60: 233-35.

19 Adibi SA. Roles of branched-chain amino acids in metabolic regulation. J Lab Clin Med 1980; 95: 475-84.

20 Berger M, Zimmerman-Teleschow H, Berchtold P, et al. Blood amino acid levels in patients with insulin excess (functioning insulinoma) and insulin deficiency (diabetic ketosis). Metabolism 1978; 27: 793-9.

21 Pugh RNH, Murray-Lyon IM, Dawson JL, Pietroni MC, Williams R. Transection of the oesophagus for bleeding oseophageal varices. B J Surg 1973; 60: 646-9.

22 Yalow RS, Berson SA. Immunoassay of endogenous plasma insulin in man. J Clin Invest 1960; 39: 1157-75.

23 Armitage P. Statistical methods in medical research. Oxford: Blackwell Scientific Publications, 1971.

24 Desai SP, Moldawer LL, Bistrian BR, Blackburn GL, Bothe A, Schulte RD. Amino acid and protein metabolism in humans using $\mathrm{L}-\left(\mathrm{U}^{14} \mathrm{C}\right)$ tyrosine and $\mathrm{L}-\left(1^{1+} \mathrm{C}\right)$ leucine. In: Walser $\mathrm{M}$, Williamson JR, eds. Metabolism and clinical implications of branched chain amino and keto acids. Elsevier: North Holland, 1981: 307-12.

25 Carmichael MJ, Clague MB, Keir MJ, Johnston IDA Whole body protein turnover, synthesis and break- down in patients with colorectal carcinoma. Br J Surg 1980; 67: 736-9.

26 Rogaly E, Clague MB, Carmichael MJ, Wright PD, Johnston IDA. Comparison of body protein metabolism during the total parenteral nutrition using glucose or glucose and fat as the energy source. Clin Nutr 1982; 1: $81-90$.

27 Sherwin R, Joshi P, Hendler R, Felig P, Conn HO. Hyperglucagonaemia in Laennec's cirrhosis. New Engl J Med 1974: 290: 239-42.

28 Walker WF, Johnston IDA. The metabolic basis of surgical care. London: William Heineman, 1971.

29 Garlick PJ, Clugston GA, Swick RW, Waterlow JC. Diurnal pattern of protein and energy metabolism in man. Am J Clin Nutr 1980; 33: 1983-6.

30 Buse MG, Reid SS. Leucine: a possible regulator of protein turnover in muscle. J Clin Invest 1975; 56: 1250-61.

31 Goldberg AL, Chang TW. Regulation and significance of amino acid metabolism in skeletal muscle. Federation Proceedings 1978; 37: 2301-7.

32 Blackburn GL, Moldawer LL, Usui S, Bothe A, O'Keefe SJD, Bistrian BR. Branched chain amino acid administration and metabolism during starvation, injury and infection. Surgery 1979; 86: 307-15.

33 Kirsch RE, Frith LO, Saunders SJ. Stimulation of albumin synthesis by keto analogues of amino acids. Biochim Biophys Acta 1976; 442: 437-41. 